\title{
A developmental mutation (npfL1) resulting in cell death in Physarum polycephalum
}

\author{
Juliet Bailey, ${ }^{1 *}$ Lilianna SolniCa-Krezel,${ }^{2} \dagger$ Roger W. ANDERSON ${ }^{3}$ and JenNifer DeE ${ }^{1}$ \\ ${ }^{1}$ Department of Genetics, University of Leicester, University Road, Leicester LE1 7RH, UK \\ ${ }^{2}$ McArdle Laboratory for Cancer Research, 1400 University Avenue, Madison, Wisconsin 53706, USA \\ ${ }^{3}$ Department of Molecular Biology and Biotechnology, University of Sheffield, Sheffield S10 2TN, UK
}

(Received 26 May 1992; revised 30 July 1992; accepted 14 August 1992)

\begin{abstract}
In Physarum, microscopic uninucleate amoebae develop into macroscopic multinucleate plasmodia. In the mutant strain, RA614, plasmodium development is blocked. RA614 carries a recessive mutation (npfL1) in a gene that functions in sexual as well as apogamic development. In $n p f L^{+}$apogamic development, binucleate cells arise from uninucleate cells by mitosis without cytokinesis at the end of an extended cell cycle. In $n p f L 1$ cultures, apogamic development became abnormal at the end of the extended cell cycle. The cells developed a characteristic rounded, vacuolated appearance, nuclear fusion and vigorous cytoplasmic motion occurred, and the cells eventually died. Nuclei were not visible by phase-contrast microscopy in most of the abnormally developing cells, but fluorescence microscopy after DAPI staining revealed intensely staining, condensed nuclei without nucleoli. Studies of tubulin organization during $n p f L 1$ development indicated a high frequency of abnormal mitotic spindles and, in some interphase cells, abnormally thick microtubules. Some of these features were observed at low frequency in the parental $n p \mathrm{fL}^{+}$strain and may represent a pathway of cell death, resembling apoptosis, that may be triggered in more than one way. Nuclear fusion occurred during interphase and mitosis in $n p f L 1$ cells, and multipolar spindles were also observed. None of these features were observed in $n p \mathrm{fL}^{+}$cells, suggesting that a specific effect of the npfLI mutation may be an incomplete alteration of nuclear structure from the amoebal to the plasmodial state.
\end{abstract}

\section{Introduction}

The life cycle of the acellular slime mould Physarum polycephalum includes two vegetative growth phases uninucleate, haploid amoebae and multinucleate, syncytial plasmodia - which differ greatly in their patterns of gene expression and cellular organization (Gull et al., 1985; Sweeney et al., 1987). The transition from amoeba to plasmodium is normally a heterothallic (sexual) process controlled by the multiallelic mating-type locus mat $A$; for plasmodium formation to occur, fusing amoebae must carry different alleles of mat $A$ (Burland,

\footnotetext{
* Author for correspondence. Tel. (0533) 523414; fax (0533) 523378
}

† Present address: Cardiovascular Research Center, Massachusetts General Hospital East 4, Bldg 149, 13th St, Charlestown, MA 02129, USA.

Abbreviations: IMT, intermitotic time; DAPI; 4,6-diamidine-2phenylindole; MTOC, microtubule organizing centre.
1986). Time-lapse cinematography of sexual plasmodium formation has shown that nuclear fusion occurs shortly after amoebal fusion and the resulting diploid zygote enters an extended cell cycle at the end of which it becomes binucleate by mitosis without cytokinesis (Bailey et al., 1990). In apogamic strains, a haploid amoeba develops into a haploid plasmodium; such strains result from gad mutations which map at mat $A$ (gad = greater asexual differentiation; Adler \& Holt, 1977). In the apogamic strain CL, binucleate plasmodium formation is preceded by an extended cell cycle of similar length to that observed in sexual development (Anderson et al., 1976; Bailey et al., 1987). During the extended cell cycle in both sexual and apogamic development, uninucleate cells become committed to plasmodium formation (Youngman et al., 1977; Burland et al., 1981) and many of the changes in cellular organization that accompany development are initiated (Blindt, 1987; Bailey et al., 1990; Solnica-Krezel et al., 1990, 1991). 
Interphase amoebae possess a cytoplasmic microtubular network which radiates from a nucleus-associated microtubule organizing centre (MTOC). This MTOC is closely associated with a pair of centrioles and is attached to the nucleus (Havercroft \& Gull, 1983). At mitosis, the nuclear membrane breaks down, and the MTOC and centrioles duplicate, divide and migrate to form the poles of the spindle. In contrast, plasmodial nuclei undergo synchronous anastral mitoses inside intact nuclear membranes (Havercroft \& Gull, 1983) and the interphase microtubules of plasmodia are cytoplasmic with no obvious association with the nuclei (Salles-Passador $e t$ $a l ., 1991)$. Thus the alteration from amoebal to plasmodial microtubule organization involves changes in the numbers of MTOCs per cell, the arrangement of the cytoplasmic microtubules and the type of mitosis. The time course of these changes has been studied in the apogamic strain CL (Gull et al., 1985; Blindt, 1987; Solnica-Krezel et al., 1990, 1991). The earliest stage at which a plasmodial spindle has been observed is at the mitosis at which a binucleate cell is formed. Although most cells form plasmodial spindles at this mitosis, a significant number form other types of spindles (SolnicaKrezel et al., 1991). Extra MTOCs that are not nucleating the spindle are frequently observed at this mitosis in CL (Blindt, 1987; Solnica-Krezel et al., 1991). These MTOCs are presumed to be the remnants of the amoebal MTOCs which do not function in intranuclear plasmodial mitosis. Most developing uninucleate cells possess a single MTOC but binucleate cells display variability in the number of MTOCs they possess (Blindt, 1987; Solnica-Krezel et al., 1990).

The distribution of two phase-specific tubulin isotypes has been studied in CL. The $\alpha 3$ tubulin isotype is an acetylated form of the $\alpha 1$-isotype and, in amoebae, is found only in the centrioles during interphase and in the spindle poles during mitosis. The $\alpha 3$-isotype is not detectable in plasmodia. The loss of the $\alpha 3$-isotype begins during the extended cell cycle, but in some cells it does not completely disappear until the quadrinucleate stage (Solnica-Krezel et al., 1990). In contrast, the $\beta 2$-isotype is not present in amoebae and is first expressed shortly after cells become committed to development, although there is variability in the time at which individual cells first show this marker of development (Solnica-Krezel $e t$ al., 1990).

The apogamic strain CL arose as a result of a gad mutation $(\mathrm{gad} A h)$ in a mat $A 2$ strain and the cellular events leading to plasmodium formation in this strain have been well studied (Anderson, 1979; Blindt et al., 1986; Bailey et al., 1987; Solnica-Krezel et al., 1990, 1991). Other independently isolated gad mutants have been characterized genetically; for example, the apogamic strain RA376 arose as a result of a mutation
(gadA111) in a matA3 strain (Shinnick \& Holt, 1977; Anderson et al., 1989). However, the cellular events of plasmodium development in these other $g a d$ strains have not been reported.

From apogamic gad strains, a number of npf (no plasmodium formation) mutants have been isolated in which plasmodium formation is blocked. Since $n p f$ strains proliferate as amoebae but cannot complete development, the mutations they carry identify genes essential for plasmodium formation but not required for vegetative amoebal growth. In strains where the $n p f$ mutation maps at mat $A$, there is no evidence that development is initiated (Anderson \& Dee, 1977; R. W. Anderson, unpublished observations). Mutations that map at loci other than matA give rise to strains in which development is initiated but halts before a mature plasmodium forms (Anderson et al., 1986). Such strains exhibit a variety of abnormal phenotypes. One of these strains, RA614, is the subject of the present work.

Amoebal growth was normal in RA614 but this strain failed to complete the transition from amoeba to plasmodium. First we verified that the mutant phenotype resulted from a single gene mutation. We then used a variety of techniques to determine the earliest stage at which development became detectably abnormal, and the sequence of events leading to the terminal phenotype. Since RA614 was isolated from the apogamic strain RA376, and the cellular events of plasmodium formation in the parental strain had not previously been elucidated, development was studied in RA376 also.

\section{Methods}

Media. SDM (semi-defined medium), DSDM agar (agar containing SDM), and LIA (liver infusion agar): Blindt et al. (1986). LIA + citrate (liver infusion agar with citrate buffer): Bailey et al. (1987). SM-1: Dee \& Anderson (1984). SM-4: $33 \mathrm{ml}$ Solution A (20 g Difco bacto tryptone, $6 \mathrm{~g}$ Difco yeast extract, $18 \mathrm{~g}$ glucose plus water to 11 ) and $6 \mathrm{ml}$ Solution B $(36.8 \mathrm{~g}$ citric acid monohydrate, $95.5 \mathrm{~g}$ trisodium citrate dihydrate plus water to 11 ) to 11 molten $1.5 \%$ agar. SBS (standard bacterial suspension): Burland et al. (1981). FKB (formalin killed bacterial suspension): Dee (1986).

Culture conditions. Apogamic plasmodium development is temperature-sensitive. Studies of apogamic development were carried out on DSDM or LIA + citrate at $21-22^{\circ} \mathrm{C}$, the permissive temperature for development. Experiments with vegetative amoebae were carried out on LIA at $28.5-29.5^{\circ} \mathrm{C}$, the nonpermissive temperature for apogamic development in the strains used. Amoebal stocks were also maintained at $28 \cdot 5-29 \cdot 5^{\circ} \mathrm{C}$. Genetic analysis of RA614 was carried out on SM-1 or SM-4 as given below.

Loci. These loci are described in detail in Anderson et al. (1989). matA : mating-type locus controlling zygote differentiation. Heterozygosity at this locus is essential for plasmodium formation. mat $B$, mat $C$ : mating-type loci affecting the frequency of zygote formation. fus $A$, fusC: plasmodial fusion compatibility loci. whiA: plasmodial colour gene. Plasmodia expressing the recessive whiAl allele are white; wildtype plasmodia are yellow. $\operatorname{gadA}: \operatorname{gadA}$ mutations allow amoebae to 
develop into plasmodia without mating; they are tightly linked to matA and dominant to gad $A^{+}$. npf (no plasmodium formation): Mutations at these loci block plasmodium development.

Strains. CH818: matA2 gadAh npfFl npfL ${ }^{+}$(Anderson, 1979). CH938: at A4 gad ${ }^{+}$npf $L^{+}$matB2 matCl fusAl fusCl whiAl (Kawano et al., 1987). LU867: matA2 gadAh npfAl npf $\mathrm{L}^{+}$(Anderson \& Dee, 1977). RA376: matA3 gadA111 npfL ${ }^{+}$matB3 matC2 fusA2 fusC2 whiA ${ }^{+}$ (Anderson et al., 1989). RA614: matA3 gadA111 npfL1 matB3 matC2 fusA2 fusC2 whiA $^{+}$arose as a result of mutation in RA376.

Mutagenesis of RA376 and isolation of npf derivatives. RA376 amoebae were spread, $10^{5}$ per plate, on SM-1 agar containing $0.2 \%$ caffeine. After $48 \mathrm{~h}$ incubation at $29.5^{\circ} \mathrm{C}$, the cultures were irradiated for $10 \mathrm{~s}$ at $30 \mathrm{~cm}$ from a mercury vapour lamp (T/M5/369E, Thermal Syndicate) and reincubated for $48 \mathrm{~h}$. The cells from three plates were resuspended in $3 \mathrm{ml}$ distilled water and plated on SM-4 agar with SBS at a density which gave well-separated colonies. After $7 \mathrm{~d}$ incubation at $21^{\circ} \mathrm{C}$, well-formed plasmodia were apparent in all but 35 of 3306 colonies examined. Amoebae were recovered from these colonies, purified and retested; RA614 was one of several isolates that consistently showed abnormalities in plasmodium development. Culturing and genetic analysis of RA614 amoebae were as described in Anderson et al. (1989).

Cell assays. Replicate LIA + citrate or DSDM plates were inoculated with $5 \times 10^{4}$ amoebal cysts and $0 \cdot 1 \mathrm{ml}$ of FKB suspension diluted $1: 2$ with water. The plates were incubated at $22^{\circ} \mathrm{C}$. At various times after inoculation, cells were harvested from two plates. A drop of the cell suspension was allowed to dry into the surface of an agar-coated slide and about 300 cells were examined by phase-contrast microscopy to determine the number of nuclei per cell. In some experiments, the number of cells able to undergo the amoeba-flagellate transformation was determined (Blindt et al., 1986).

Time-lapse cinematography. Filming was carried out in cavity slides using the equipment and conditions described by Bailey et al. (1987) and an initial cell density of $4 \times 10^{5}$ cysts $\mathrm{ml}^{-1}$. One frame was exposed every $30 \mathrm{~s}$ with an exposure time of $0.2 \mathrm{~s}$. Intermitotic time (IMT) was measured from nucleolar disappearance in one cell cycle to nucleolar disappearance in the next cell cycle. In the text, all times are given in hours as mean \pm standard deviation. Cell area was measured as described in Bailey et al. (1987). At the magnification used in this study, each arbitrary unit of area represents $7.30 \mu \mathrm{m}^{2}$ on the slide culture. In the text, area measurements are given in these arbitrary units as mean \pm standard deviation. It should be noted that area measurements from different films cannot be compared directly because of variation between slide cultures in the extent of cell flattening. Unless otherwise stated, all statistical analyses were performed by Student's $t$-tests.

Two films were made of development in RA614 and one of development in RA376. One of the RA614 films (Film 1) and the RA376 film showed cultures recorded from 48-114 h after inoculation with cysts and FKB. Actively growing RA614 cells, plus extra FKB, were used to inoculate the culture recorded in Film 2; this film started immediately after inoculation and continued for $66 \mathrm{~h}$.

Flow cytometry. Cultures were inoculated at a density of $5 \times 10^{5}$ cysts per plate and incubated at $22^{\circ} \mathrm{C}$ (developing cultures on LIA + citrate plates) or $29.5^{\circ} \mathrm{C}$ (amoebal controls on LIA plates). After a period of growth, the cells were harvested and stained for flow cytometry (Bailey et al., 1987). Before staining, a sample was removed and the number of nuclei in each cell was determined by phase-contrast microscopy. The stained cells were examined on a FACS 420 flow cytometer linked to a Consort 30 accessory computer (Becton-Dickinson Immunocytometry Systems). The intensity of fluorescence emitted by each cell is directly proportional to its DNA content (Crissman \& Tobey 1974; Taylor \& Milthorpe 1980).
Fluorescence microscopy. Cultures were set up as for flow cytometry. After $3 \mathrm{~d}$ of growth at $22^{\circ} \mathrm{C}$, the cells from two plates were used to determine the number of nuclei visible in a sample of cells. The cells on the remaining plates were fixed and stained with antibodies and DAPI (4',6-diamidino-2-phenylindole) as described in Bailey et al. (1990) or as in Diggins-Gilicinski et al. (1989) with modifications for the $\alpha 3$-tubulinspecific antibody 6-11B-1 as described in Solnica-Krezel et al. (1990). The stained coverslips were then mounted in antifade ( $p$-phenylenediamine; Sigma) as described in Solnica-Krezel et al. (1990).

\section{Results}

\section{Comparison of wild-type and mutant phenotypes}

Amoebal cultures of RA376, the wild-type parent strain, gave rise to small plasmodia (1-2 mm diameter) after 3$5 \mathrm{~d}$; these plasmodia were highly motile and possessed a characteristic fan shape with veins. Phase-contrast microscopy of RA376 cultures revealed that small developing plasmodia were irregularly shaped with a prominent slime layer and contained many food vacuoles, contractile vacuoles and nuclei (Fig. 1a). By a combination of cell fusions and mitoses unaccompanied by cytokinesis, these small plasmodia rapidly grew into yellow macroplasmodia with prominent veins. These characteristics of RA376 development are indistinguishable from development in the gad $A h$ apogamic strain CL (Bailey et al., 1987).

In cultures of the mutant strain, RA614, amoebal proliferation was normal, but developing cells appeared as amorphous blobs and macroscopic plasmodia never formed; the maximum diameter reached by developing cells was less than $1 \mathrm{~mm}$. Developing cells of RA614 were unusually rounded, surrounded by an abnormally thick slime sheath, possessed no veins, and their cytoplasm appeared denser than normal (Fig. 1b). The developing cells contained food vacuoles and contractile vacuoles, but in many cases nuclei could not be observed. These initial observations could not indicate the stage at which development became abnormal in RA614 nor whether the mutation affected plasmodium development or plasmodial growth.

\section{Genetic analysis}

To determine whether abnormal plasmodium development in RA614 was caused by a single gene mutation, the segregation of the mutant 'blob' phenotype was studied in the meiotic progeny of a cross between RA614 and a heterothallic strain that was wild-type except for a plasmodial colour mutation (Table $1 a$ ). Among 49 progeny analysed, 24 began apogamic plasmodium formation at the permissive temperature, $21^{\circ} \mathrm{C}$, and had therefore inherited the gadA111 allele from RA614. 

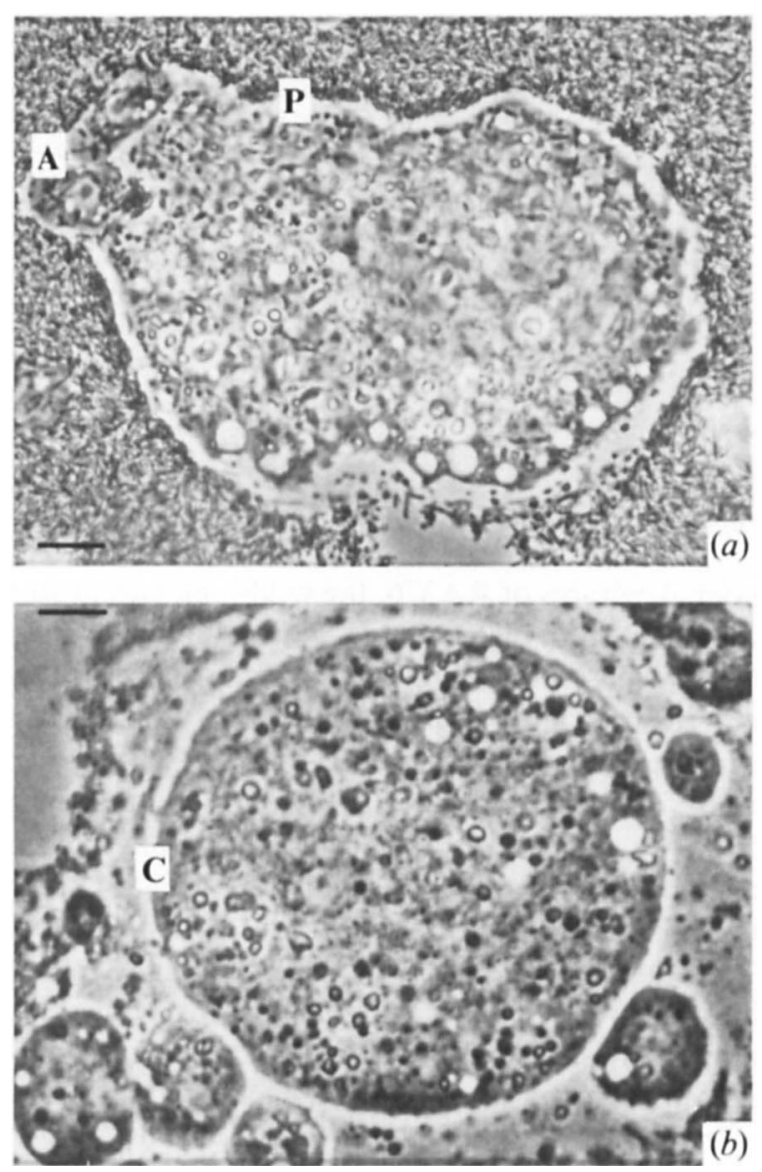

Fig. 1. Phase-contrast micrographs of apogamic amoebae allowed to develop for a few days on a bacterial lawn. (a). RA376: a normally differentiating microplasmodium $(\mathrm{P})$ is visible in contact with two amoebae (A). (b) RA614: a large cell (C) showing terminal mutant phenotype. Bar, $10 \mu \mathrm{m}$.

Apogamic development in 12 of these progeny gave rise to cells of the mutant phenotype, and 12 formed wildtype plasmodia (Table 1a). This 1:1 segregation of plasmodial morphologies indicated that the developmental abnormalities shown by RA614 were due to a mutation at a locus that was unlinked to $\operatorname{gad} A$; this mutation was designated $n p f L I$.

All the progeny were classified for mat $A$ allele (Table $1 a$ ) by mixing them with $n p f L^{+}$tester strains at $29.5^{\circ} \mathrm{C}$, a temperature that was non-permissive for apogamic development, but permissive for mating. As expected, since gadA and mat $A$ were known to be tightly linked (Anderson et al., 1989), all the gadA111 progeny carried the mat $A 3$ allele from RA614, and all the gad $A^{+}$progeny carried the mat $A 4$ allele from the wild-type parent. The $25 \operatorname{gadA}^{+}$mat $A 4$ progeny were then mixed with a mat $A 3$ $n p f L 1$ strain and cultured at $29.5{ }^{\circ} \mathrm{C}$. Sexual plasmodium formation began in each of these mixtures, but cultures containing eight of the 25 progeny gave rise only to cells of the mutant phenotype, showing that the $n p f L I$ mutation affected sexual, as well as apogamic, development. Seventeen progeny formed wild-type plasmodia in these mixtures, confirming that $n p f L 1$ and $n p f L^{+}$were segregating among the $\operatorname{gadA}^{+}$mat 44 progeny, and indicating that the wild-type allele was dominant. The deviation from 1:1:1:1 (Table 1a) amongst the four progeny classes of the cross between RA614 and the wild-type strain was not significant (Chi-square test; $p>0 \cdot 3$ ), confirming that the $n p f L$ gene was unlinked to mat $A$ and $\operatorname{gad} A$.

The progeny of the cross were also segregating for several additional markers known to be unlinked to mat $A$ and to each other (mat B, matC, fus $A$, fus $C$, whi $A$; Methods). All progeny were classified for these markers, but no significant deviation from free recombination with $n p f L$ was detected in any case (Table $1 b ; p>0.05$, Chi-square tests). Further crosses were analysed between RA614 and strains carrying $n p f A l$ (LU867; Anderson \& Dee, 1977) or $n p f F 1$ (CH818; Anderson, 1979), two other developmental mutations known to be unlinked to mat $A$. No significant deviation from free recombination was found with either mutation (Table $1 b ; p>0.05$, Chisquare test). Thus the npfLI mutation carried by RA614 was not linked to any of the genes tested.

\section{The amoeba-flagellate transformation and binucleate cell formation}

In the parent strain RA376, as in CL (Blindt et al., 1986; Bailey et al., 1987), commitment occurred about half way through the extended cell cycle, very close to the time that ability to undergo the amoeba-flagellate transformation was lost and several hours before binucleate cell formation (data not shown). Since the assay for commitment depends upon the formation of macroscopic motile plasmodia, it was not possible to determine the time of commitment in the $n p f L I$ mutant strain. It was possible, however, to assay cells in developing cultures of the mutant strain for loss of ability to undergo the amoebaflagellate transformation and for the presence of binucleate cells. In developing cultures that contained only uninucleate cells, most cells $(94 \%)$ were able to transform into flagellates. When $0.2 \%$ of cells had reached the binucleate stage, the proportion of cells able to undergo the amoeba-flagellate transformation had declined to $87 \%$; the proportion continued to decline, reaching $41 \%$ when $3 \%$ of the cells were binucleate. The decline in the proportion of cells able to undergo the amoeba-flagellate transformation suggested that many uninucleate cells had initiated plasmodium development. The presence of binucleate cells in the cultures indicated that some cells had passed the developmental stage at which commit- 
Table 1. Genetic analysis of RA614

(a) Classification of progeny from the cross $\mathrm{RA} 614 \times \mathrm{CH} 938$

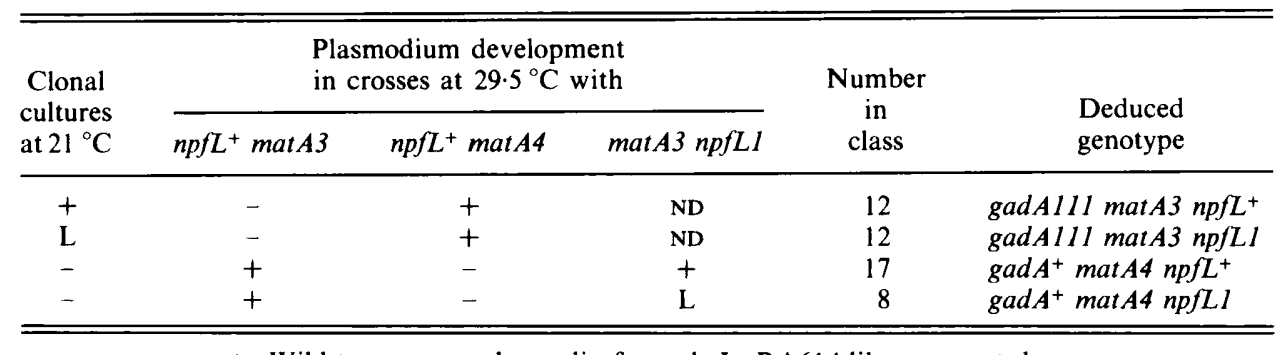

+, Wild-type; -, no plasmodia formed; L, RA614-like; ND, not done.

(b) Recombination of $n p f L$ and other loci

\begin{tabular}{llc}
\hline \hline Cross & Locus & Recombinants : parentals \\
\hline RA614 $\times$ CH938 & mat B & $28: 21$ \\
& matC & $27: 22$ \\
& fus $A$ & $29: 20$ \\
& fusC & $30: 19$ \\
RA614 $\times$ LU867* & whiA & $25: 24$ \\
RA614 $\times$ CH818† & nff $A$ & $14: 12$ \\
\hline \hline
\end{tabular}

* Only scored in matA2 gadAh $n p f A^{+}$progeny (26/99).

† Only scored in matA2 gadAh $n p f F^{+}$progeny (27/99).

ment normally occurs and were presumably committed to development.

To identify the stage of development at which the $n p f L I$ lesion first affected plasmodium formation, the proportions of cells with different numbers of nuclei were determined by phase-contrast microscopy of RA614 cultures at various times after inoculation. In developing cultures of the apogamic strain CL, binucleate cells were first detected at about $48-60 \mathrm{~h}$ of development; the number of binucleate cells rose rapidly for a short time and then cells with more than two nuclei were detected (Blindt et al., 1986). Developing CL plasmodia readily fused to give large plasmodia that appeared some hours after the first multinucleate cells were observed (Bailey et al., 1987). In developing $n p f L I$ cultures, all the cells were uninucleate for the first $60 \mathrm{~h}$ of incubation (Fig. 2). After this time, some binucleate cells were detected but they never exceeded $5 \%$ of the population. No cells with more than 2 nuclei were detected but a new cell-type was observed in which nuclei were not visible by phase-contrast microscopy. These apparently anucleate cells were first detected at $78 \mathrm{~h}$ and their numbers increased rapidly to $30 \%$ at $100 \mathrm{~h}$. At the end of the experiment $(168 \mathrm{~h})$, nuclei were not visible in $36 \%$ of the cells, $5 \%$ were binucleate and the remainder were uninucleate (Fig. 2). These results confirmed that development was initiated in $n p f L 1$ cells but became abnormal before the end of the binucleate cell stage with the accumulation of large numbers of apparently anucleate cells.

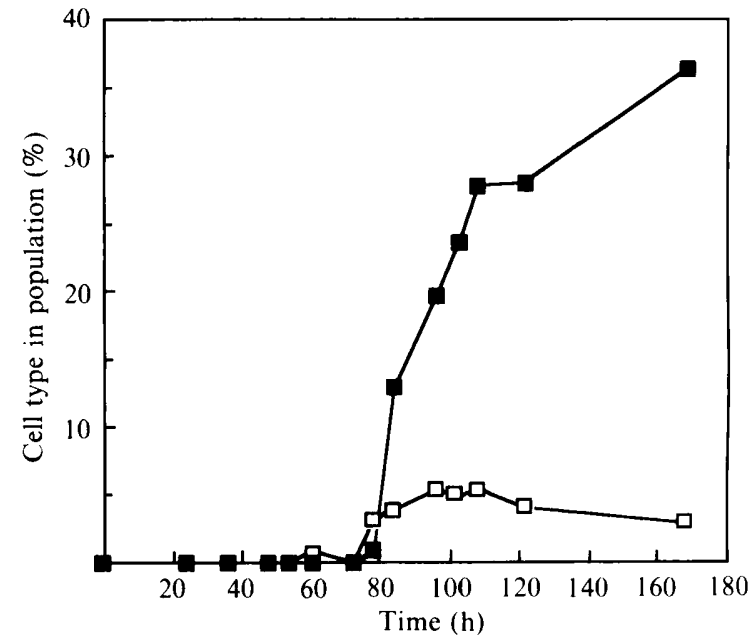

Fig. 2. Cell types during development in RA614. The percentages of uninucleate, binucleate and apparently anucleate cells in developing cultures were determined at different times after inoculation as described in Methods. Binucleate cells $(\square)$ and anucleate cells ( $\square$ ) are shown; the remaining cells were uninucleate.

\section{Origin of abnormal cells}

To investigate the origin of the apparently anucleate cells during development of RA614, time-lapse cinematography was used to trace individual cells through successive cell cycles. Two films were made of development in RA614 (Methods). For comparison, cinematographic 
Table 2. Time-lapse cinematographic data

Times are given as the mean (h) \pm SD; the number of observations $n$ is given in parentheses.

\begin{tabular}{|c|c|c|c|}
\hline \multirow[b]{2}{*}{ Measurement } & \multirow[b]{2}{*}{ RA376 } & \multicolumn{2}{|c|}{ RA614 } \\
\hline & & Film 1 & Film 2 \\
\hline $\begin{array}{l}\text { Amoebal IMT } \\
\text { Uninucleate to binucleate IMT }\end{array}$ & $\begin{array}{l}13.4 \pm 3.0 \mathrm{~h}(n=24) \\
29.7 \pm 4 \cdot 2 \mathrm{~h}(n=10)\end{array}$ & $\begin{array}{l}13.1 \pm 1.8 \mathrm{~h}(n=38) \\
32.8 \pm 1.4 \mathrm{~h}(n=3)\end{array}$ & $\begin{array}{l}10 \cdot 3 \pm 3 \cdot 3 \mathrm{~h}(n=20) \\
24 \cdot 5 \pm 2 \cdot 7 \mathrm{~h}(n=7)\end{array}$ \\
\hline IMT for cells that divided after long cell cycle & $31 \cdot 3 \mathrm{~h}(n=1)$ & $29.0 \mathrm{~h}(n=1)$ & $28.6 \pm 5.4 \mathrm{~h}(n=3)$ \\
\hline Amoebal area at birth & $10.6 \pm 1.6(n=23)$ & $14.9 \pm 3.0(n=38)$ & 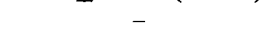 \\
\hline Amoebal area at mitosis & $23 \cdot 4 \pm 5 \cdot 6(n=23)$ & $34.0 \pm 6.0(n=38)$ & - \\
\hline Area at start of long cell cycle & $15.6 \pm 5.0(n=10)$ & $16.8 \pm 2.7(n=4)$ & - \\
\hline Area at end of long cell cycle & $58.0 \pm 21.6(n=10)$ & $71 \cdot 3 \pm 20 \cdot 3(n=4)$ & - \\
\hline
\end{tabular}

analysis was also carried out on the parental strain, RA376. Amoebal proliferation appeared normal in both strains; amoebal area approximately doubled in each cell cycle and amoebal IMTs were of similar length in RA376 and RA614 (Film 1; Table 2). The mean npfL1 (RA614) amoebal IMT measured from Film 2 was significantly shorter than that measured from Film $1(p<0.005)$, presumably due to the difference in the growth state of the cells used to set up the slide cultures (Methods).

Most of the developing cells in both films of RA614 eventually developed the characteristic abnormal phenotype of $n p f L 1$ which began with the disappearance of the nuclei from view, the cessation of locomotion and the rounding up of the cells; these features often appeared within a few minutes. At about the same time, the cells began to accumulate contractile vacuoles and the cytoplasm began to move vigorously, appearing as 'boiling' under rapid playback. This vigorous cytoplasmic motion often continued for over $24 \mathrm{~h}$, during which time the cells became smaller and some eventually burst. Although the abnormal $n p f L 1$ cells failed to locomote, they ingested passing amoebae and underwent apparently normal plasmodial fusions with developing cells that were still locomoting. In addition, they developed the prominent slime layer and rhythmic pulsations characteristic of plasmodia. Since no plasmodia ever formed in RA614 cultures, we assume that all cells would have eventually developed the characteristic abnormal phenotype and died.

Although the terminal phenotype shown by developing RA614 cells was always essentially the same, there was wide variation in the history of the cells that developed this phenotype. Some of these pathways are illustrated in Fig. 3. As in all apogamic strains studied, including RA376, development involved an extended cell cycle about $2 \cdot 3$ times the length of an amoebal cell cycle during which the developing cells continued to grow until they were about twice the area of amoebae at mitosis (Table 2). Fourteen RA614 cells entered this long cell cycle, at the end of which 10 became binucleate (Fig.

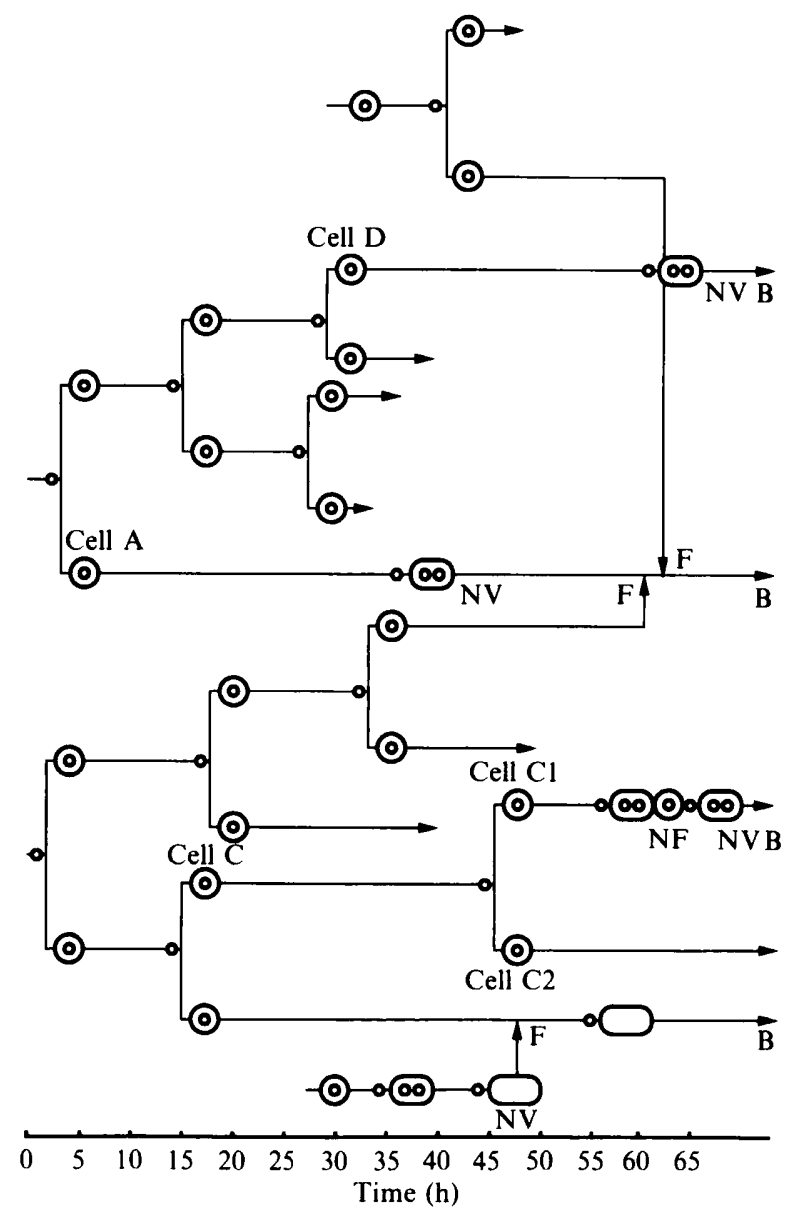

Fig. 3. Representative RA614 cell pedigree from time-lapse cinematography. Time is given in hours after the start of filming. NV, nuclei vanish; F, cell fusion; NF, nuclear fusion; B, approximate time of onset of boiling phenotype. $\odot$, Uninucleate cell; $\circledast$, binucleate cell; $\bigcirc$, cell in which no nuclei are visible; $\bullet$, time of nucleolar disappearance at start of mitosis; $\rightarrow$, cell left field of view.

3, Cells A, D) and 4 divided to give two daughter cells each (a total of 8 daughter cells; Fig. 3, cell C); in RA376, nine cells became binucleate and one cell divided. All RA614 and RA376 cells that entered the extended cell 
Table 3. Nuclear morphology during development

\begin{tabular}{|c|c|c|c|c|}
\hline \multirow[b]{2}{*}{ Cell type } & \multicolumn{2}{|c|}{ Percentage in RA376 (npfL $\left.L^{+}\right)$} & \multicolumn{2}{|c|}{ Percentage in RA614 (npflL $)$} \\
\hline & Phase contrast & DAPI & Phase contrast & DAPI \\
\hline Uninucleate & $88 \cdot 2$ & $85 \cdot 7$ & $78 \cdot 1$ & $77 \cdot 9$ \\
\hline Binucleate & 7.8 & $4 \cdot 0$ & $5 \cdot 5$ & $6 \cdot 1$ \\
\hline More than four nuclei & 1.4 & $3 \cdot 3$ & $0 \cdot 0$ & 1.8 \\
\hline Mitotic & 0.9 & $4 \cdot 0$ & $0 \cdot 8$ & $3 \cdot 0$ \\
\hline One condensed nucleus & $0 \cdot 0$ & 1.7 & 0.0 & $3 \cdot 3$ \\
\hline Two condensed nuclei & 0.0 & $1 \cdot 3$ & 0.0 & $6 \cdot 1$ \\
\hline Four condensed nuclei & $0 \cdot 0$ & $0 \cdot 0$ & $0 \cdot 0$ & $1 \cdot 2$ \\
\hline No visible nucleus & $1 \cdot 7$ & 0.0 & $15 \cdot 6$ & 0.6 \\
\hline Total cells scored & 632 & 299 & 385 & 329 \\
\hline
\end{tabular}

cycle arose from apparently normal amoebal divisions and were not significantly different in area, at birth, from cells that continued to cycle vegetatively (Table 2 ; both strains, $p<0.005$ ).

Seven of the cells that became binucleate after the extended cell cycle could be traced further. Of the 8 daughter cells resulting from division at the end of the long cell cycle, five became binucleate after an approximately amoebal length cell cycle (Fig. 3, Cell $\mathrm{Cl}$ ); one RA376 daughter cell also became binucleate in this manner. In addition, the fates of five cells that entered the field of view as uninucleates and later became binucleate could be traced. Thus, the fates of a total of 17 RA614 cells observed to become binucleate could be traced. In 10 binucleate cells, the nuclei vanished in interphase (NV in Fig. 3; Cells A, D) and the cells exhibited the characteristic 'boiling' phenotype of the mutant (B in Fig. 3). In another three binucleate cells, the nuclei vanished after the start of mitosis and the cells developed the characteristic $n p f L 1$ phenotype. The nuclei of the remaining four binucleate cells underwent nuclear fusion in interphase, giving rise to uninucleate, presumably diploid, cells (Fig. 3, cell C1). In two of these cells, the nuclei subsequently vanished in interphase. The other two uninucleate diploid cells became binucleate by mitosis without cytokinesis before the two nuclei in each cell vanished and the cells began to show the abnormal characteristics of npfL1. Two RA376 binucleate cells also developed the vigorous cytoplasmic motion characteristic of RA614 after their nuclei vanished in interphase.

Three RA614 cells entered the field as binucleate cells and underwent mitosis without cytokinesis to give rise to quadrinucleate cells. All of these subsequently developed the characteristic $n p f L 1$ phenotype. In one of the three quadrinucleate cells, the nuclei vanished at mitosis (Fig. 3 ) and the characteristic phenotype developed. In the other two quadrinucleate cells, the four nuclei entered mitosis synchronously some hours after the previous mitosis, but instead of eight nuclei being formed, only one or two giant, presumably polyploid, nuclei were observed. These nuclei eventually vanished and the characteristic phenotype developed.

The films showed that development in the apogamic strains CL, RA376 and RA614 was similar until the end of the extended cell cycle. In RA614, development became abnormal close to the end of the extended cell cycle and all the developing cells eventually developed the characteristic 'boiling' phenotype, although the pathways leading to this phenotype were varied. Nuclear fusion at mitosis and in interphase was observed only in RA614 but other abnormalities seen in RA614 also occurred in a few cells of RA376. Nuclear disappearance in interphase occurred in two developing RA376 cells and these subsequently developed the same terminal phenotype as RA614.

\section{Nuclear morphology during development}

Filming indicated that the disappearance of nuclei was an early event in the abnormal development of RA614. In order to determine whether the nuclei had fragmented or were present in a form that was not detectable by phase-contrast microscopy, the nuclei in samples of cells from both RA614 and RA376 were examined by phasecontrast microscopy and by DAPI fluorescence microscopy. The DAPI-stained cells were also stained with a $\beta$-tubulin antibody to visualize microtubules.

For both strains, the different microscopical techniques made little difference to the proportions of uninucleate or multinucleate cells (Table 3 ). The frequency of mitotic cells detected by fluorescence microscopy was slightly higher than by phase-contrast microscopy (Table 3) since the condensed chromosomes of mitotic cells were visualized more clearly by DAPI staining. By phase-contrast microscopy, some cells of each strain appeared anucleate; the frequency of such 


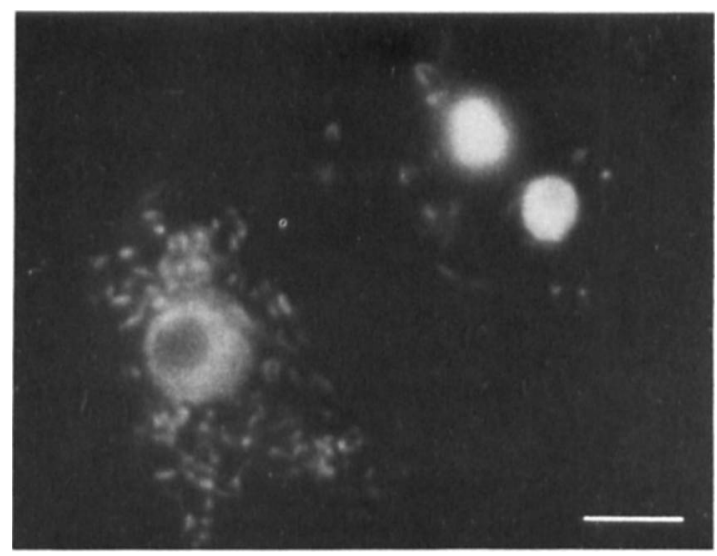

Fig. 4. Fluorescence micrograph of two DAPI-stained RA614 cells. One has a single normal interphase nucleus, the other has two condensed nuclei. DAPI also stains the DNA in mitochondria and in ingested bacteria in the cytoplasm. Bar, $5 \mu \mathrm{m}$.

cells was much higher in RA614 ( $n p f L 1$ ) than in RA376 $(15.6 \%$ compared to $1.7 \%$; Table 3$)$. By DAPI-fluorescence microscopy, about $1 \%$ of RA614 cells were anucleate but no anucleate RA376 cells were observed (Table 3); to avoid possible confusion between genuine anucleate cells and debris on the slides, structures observed by DAPI-fluorescence were not classified as anucleate cells unless tubulin staining confirmed the presence of microtubules. By fluorescence microscopy, cells with condensed nuclei were detected in each strain; such cells were more frequent in $n p f L 1$ cultures than in $n p f L^{+}$cultures (Table $3 ; 10.6 \%$ compared with $3.0 \%$ ). Condensed nuclei were $25-50 \%$ the area of normal nuclei, did not exhibit nucleoli and stained uniformly and very brightly with DAPI (Fig. 4). These nuclei were distinctly different from mitotic nuclei, in which condensed chromosomes were observable (Fig. 6). Condensed nuclei were not visible by phase-contrast microscopy. These results suggested that many of the cells scored as anucleate by phase-contrast microscopy were those that contained condensed nuclei when viewed by fluorescence microscopy. Nuclear 'disappearance' in interphase during filming would therefore be due to nuclear condensation.

\section{DNA content during development}

The nuclear fusions observed during filming of $n p f L 1$ cells suggested that some $n p f L I$ uninucleate cells were not haploid, as is usual in apogamic strains, but diploid. Our studies of nuclear morphology in RA614 indicated that most of the cells that appeared anucleate by phasecontrast microscopy contained two or more condensed nuclei (Table 3). Both these observations led to a
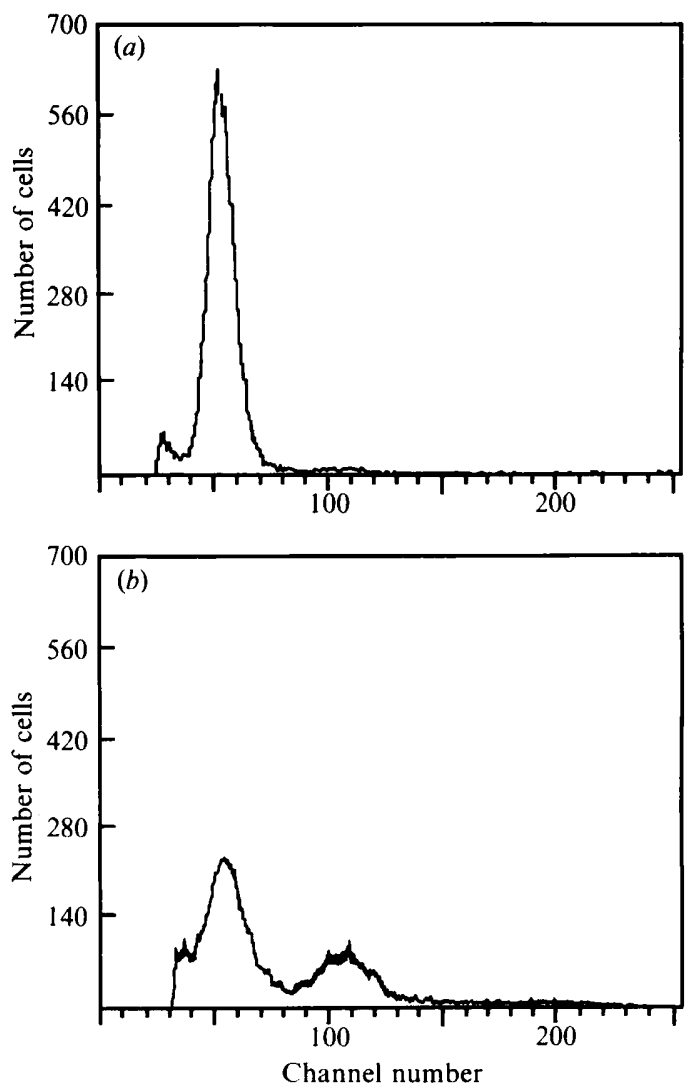

Fig. 5. Cellular DNA contents in RA614 ( $n p f L l$ ) estimated by flow cytometry. Channel number is proportional to DNA content (see Methods). For each sample, $10^{4}$ cells were counted. (a) Vegetative amoebae at $29.5{ }^{\circ} \mathrm{C}$. The main peak at Channel 50 contains $90 \%$ of cells. The remaining cells had higher DNA contents. $(b)$ Developing population at $22{ }^{\circ} \mathrm{C}$. The peaks at Channel 50 and Channel 100 contain $53 \%$ and $27 \%$ of cells respectively. The remaining cells had higher DNA contents.

prediction that, in a developing culture of RA614, the frequency of cells with a $4 \mathrm{C}$ (binucleate haploid G2) DNA content would be greater than the frequency of binucleate cells scored by phase-contrast microscopy. We therefore used flow cytometry to measure the cellular DNA contents in RA614 cultures.

Phase-contrast microscopy of an amoebal culture incubated at $29^{\circ} \mathrm{C}$ for $3 \mathrm{~d}$ indicated that it contained only uninucleate and encysted cells. Flow cytometry of the same population (Fig. $5 a$ ) showed a distribution typical of haploid amoebal cultures (Dee et al., 1989). The single main peak around Channel 50 in Fig. $5(a)$ corresponds to the 2C (haploid G2) DNA content. Phase-contrast microscopy of a developing culture incubated at $22^{\circ} \mathrm{C}$ for $8 \mathrm{~d}$ indicated that it contained $65 \%$ uninucleate cells, $1 \%$ binucleate cells and $33 \%$ apparently anucleate cells. Athough only $1 \%$ of the RA614 cells were binucleate, flow cytometry (Fig. $5 b$ ) showed, in addition to the $2 \mathrm{C}$ 

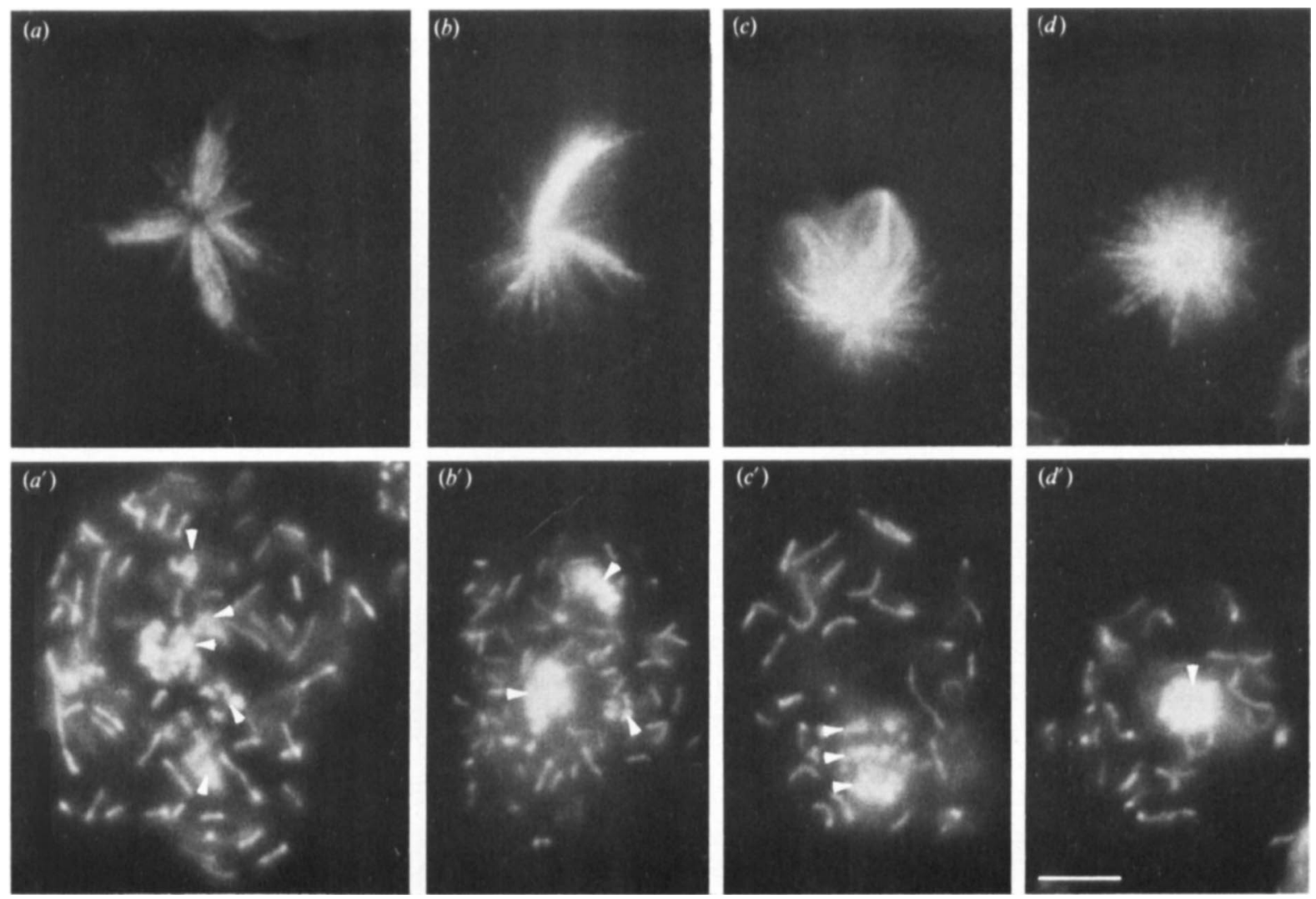

Fig. 6. Abnormal mitotic spindles in RA614 uninucleate developing cells. ( $a-d)$ Cells stained with $\beta$-tubulin antibody. $\left(a^{\prime}-d^{\prime}\right)$ The same cells double stained with DAPI. DAPI also stains the DNA in mitochondria and in ingested bacteria in the cytoplasm. Bar, $5 \mu \mathrm{m}$. Arrows indicate chromosome masses. $\left(a, a^{\prime}\right)$ Mitotic cell with a cross-shaped spindle. There is a central mass of chromatin as well as smaller clusters at each arm of the cross. $\left(b, b^{\prime}\right)$ The chromosomes in this cell are divided into three portions with one residing at each arm of the spindle. (c, $\left.c^{\prime}\right)$ Most of the chromosomes in this cell lie in or near the main group. $\left(d, d^{\prime}\right)$. This 'star' type of mitotic spindle was the most common abnormality observed. The chromatin forms a central mass and the microtubules radiate from there.

peak, a clear peak $(27 \%)$ at the $4 \mathrm{C}$ position. Thus, as predicted, there was an excess of cells with the 4C DNA content : presumably $\mathrm{G} 2$ cells with either a single diploid nucleus or two haploid nuclei.

\section{Microtubule organization during development}

We examined microtubule organization in RA614 to determine whether the npfLI mutation affected the alteration from amoebal to plasmodial microtubule organization. Cells were doubly stained with tubulin antibodies to visualise microtubules and with DAPI to show DNA.

Mitotic cells. The following types of spindles were recognised in uninucleate cells. Class I (amoebal): bipolar spindles with asters and a metaphase plate or two sets of separating chromosomes. Class II (plasmodial): bipolar spindles lacking asters, but having a metaphase plate or two sets of separating chromosomes. Class III : bipolar spindles that could not definitely be placed in Class I or Class II. These three classes of spindles were considered to be normal. Class IV: star microtubular arrays in which microtubules radiated in the form of a star and the condensed chromosomes formed a mass in the centre of the microtubular array (Fig. $6 d, d^{\prime}$ ). Class

Table 4. Frequencies of binucleate cells and abnormal uninucleate mitoses in RA614

\begin{tabular}{cccc}
\hline \hline & & \multicolumn{2}{c}{ Mitotic uninucleate cells } \\
\cline { 3 - 4 } $\begin{array}{c}\text { Binucleate cells } \\
(\%)\end{array}$ & $\begin{array}{c}\text { Mitotic cells } \\
\text { counted }\end{array}$ & $\begin{array}{c}\text { Percentage } \\
\text { Class IV (star) }\end{array}$ & $\begin{array}{c}\text { Percentage } \\
\text { Class V }\end{array}$ \\
\hline 0.0 & 399 & 0.0 & 0.2 \\
0.0 & 565 & 0.0 & 0.0 \\
0.0 & 1651 & 0.0 & 0.0 \\
1.2 & 690 & 21.4 & 2.6 \\
4.0 & 1027 & 34.0 & 4.0 \\
6.2 & 609 & 17.3 & 3.2 \\
7.6 & 584 & 43.5 & 17.5 \\
12.4 & 457 & 51.8 & 11.8 \\
14.8 & 132 & 43.2 & 16.8 \\
16.7 & 637 & 52.7 & 6.3 \\
18.9 & 327 & 45.8 & 14.7 \\
30.0 & 67 & 49.2 & 26.9 \\
\hline \hline
\end{tabular}



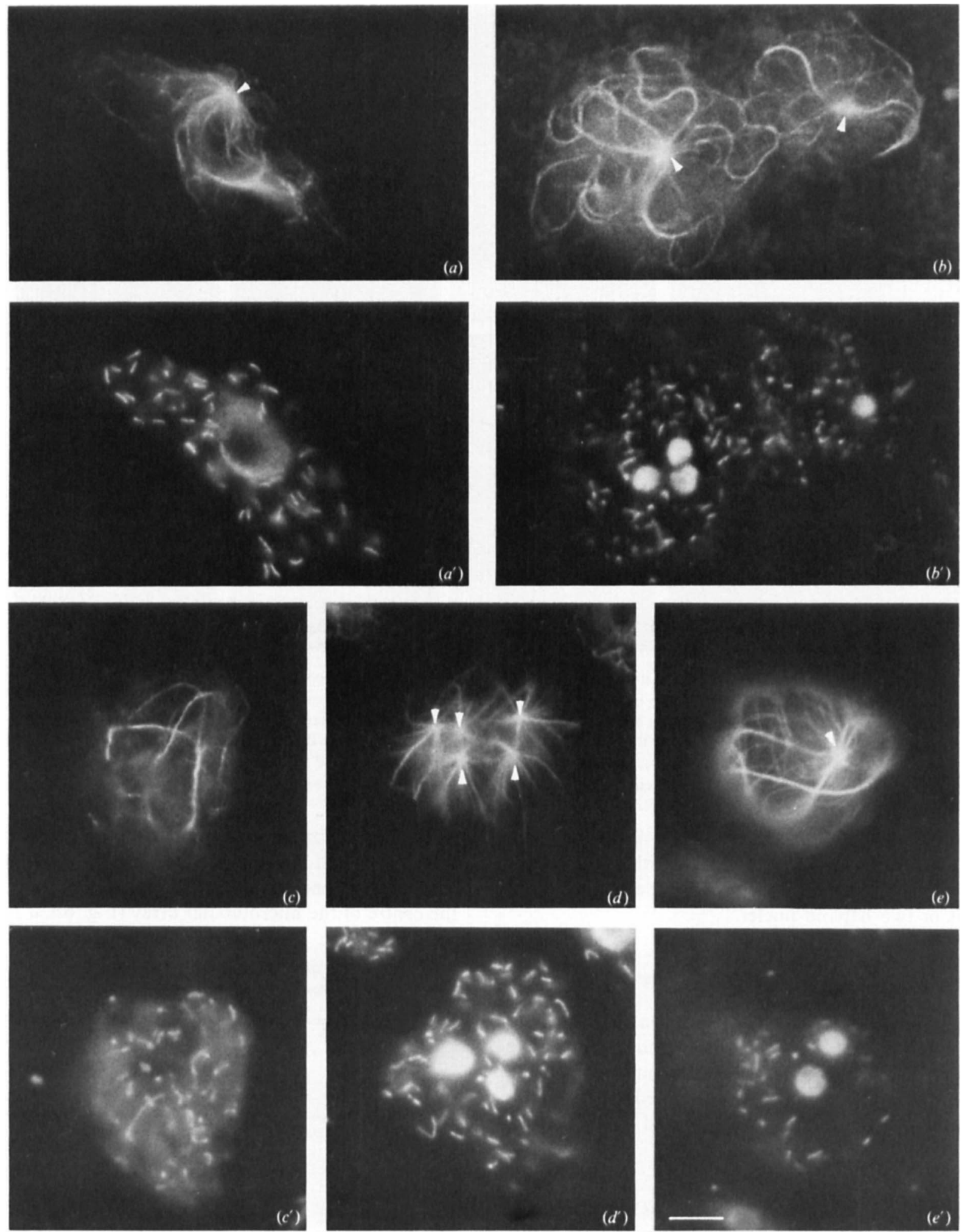

Fig. 7. Interphase microtubules in RA614 cells. (a-e) Cells stained with $\beta$-tubulin antibody. $\left(a^{\prime}-e^{\prime}\right)$ DAPI staining in the same cells. DAPI also stains the DNA in mitochondria and in ingested bacteria in the cytoplasm. Bar, $5 \mu \mathrm{m}$. MTOC. $\left(a, a^{\prime}\right)$ Normal uninucleate cell with microtubules radiating from a single MTOC. $\left(b, b^{\prime}\right)$ Quadrinucleate cell with condensed nuclei and abnormally thick microtubules which radiate from two MTOCs. $\left(c, c^{\prime}\right)$ Anucleate cell with a few thick microtubules but no MTOC. $\left(d, d^{\prime}\right)$ Five MTOCs can be seen in this cell which has three condensed nuclei. $\left(e, e^{\prime}\right)$ Thick microtubules in a cell with two condensed nuclei. 
$\mathrm{V}$ : uninucleate mitotic cells in which there were more than two spindle poles and generally several chromatin masses (Fig. $6 a-c$ ). Classes IV and V were considered to be abnormal. It was assumed that correct chromosome separation could not occur in these two classes of spindles, and that cells containing them would die.

Uninucleate cells presumed to be at the end of the extended cell cycle, selected from a culture containing $6 \%$ multinucleate cells, were scored for spindle type and for the presence of extra MTOCs. The cells were selected because all were twice the size of vegetative amoebae and some contained ingested cells. Of the 102 cells selected, 51 contained a normal spindle (Classes I, II, III) of which 20 were plasmodial (Class II). The presence of Class II (plasmodial) spindles indicated that the $n p f L 1$ mutation had not blocked the switch to the plasmodial type of mitosis. Extra MTOCs were observed in 1 of 12 Class I (amoebal) spindles; 9 of 20 Class II (plasmodial) and 4 of 19 Class III spindles. In the apogamic strain CL, extra MTOCs in mitotic cells are associated with developmental changes in microtubular organization (Blindt, 1987; Solnica-Krezel et al., 1991). Of the 102 cells selected, 51 contained an abnormal spindle (Classes IV and V; Fig. 6). Several of the Class IV (star) spindles (8/44) possessed extra MTOCs but none of the Class V spindles did. Star spindles, both with and without extra MTOCs, have also been observed in developing uninucleate cells of $\mathrm{CL}$ (Solnica-Krezel et al., 1991). Class V spindles have not been reported in $\mathrm{CL}$; we suggest they occur during mitosis of the polyploid cells that form by nuclear fusion in the mutant (see Discussion).

The frequency of abnormal spindles in all uninucleate cells was determined for RA614 cultures at different stages of development (Table 4). The proportion of binucleate cells served as a measure of the stage of development of the culture. Among mitotic uninucleate cells, the proportion with abnormal spindles increased as the frequency of binucleate cells increased. In cultures that lacked binucleate cells, and thus were in early development, few abnormal mitotic figures were observed and all of these were of the Class V type (Table 4). The proportion of abnormal mitoses, particularly of the Class IV type, increased rapidly as binucleate cells began to appear, reaching $75 \%$ when $30 \%$ binucleate cells were present.

Interphase cells. In developing cultures of RA614 that contained no multinucleate cells, $98 \%$ of cells were positive for the $\alpha 3$-tubulin isotype. As the number of multinucleate cells in the developing cultures increased, the number of $\alpha 3$-tubulin positive cells decreased; in a sulture containing $16 \%$ multinucleate cells only $73 \%$ of zells were $\alpha 3$-tubulin positive. In developing $n p f L 1$ zultures containing no multinucleate cells, less than $1 \%$ of cells were $\beta 2$-tubulin positive. As the number of multinucleate cells increased so did the number of $\beta 2$ tubulin positive cells, reaching $27 \%$ when $6 \%$ of cells were multinucleate and $55 \%$ when $22 \%$ of cells had more than one nucleus. These observations indicated that developing cultures of RA614 initiated the same changes in $\alpha 3-$ and $\beta 2$-tubulin isotype expression that accompanied development in CL (Solnica-Krezel et al., 1990).

Almost all uninucleate cells of RA376 and RA614 with a normal nucleus possessed a single MTOC (RA376: $97 \%, n=260 ;$ RA614: $86 \%, n=282$; Fig $7 a, a^{\prime}$ ). Amongst cells with two normal nuclei, both strains showed variation in MTOC number. The frequencies in RA376 $(n=156)$ and RA614 $(n=44)$ respectively were as follows : 0 MTOC $13 \%, 14 \%$; 1 MTOC $64 \%, 70 \% ; 2$ or more MTOCs $23 \%, 16 \%$. These observations reinforce the conclusion from studies of mitotic cells that the developmentally associated microtubule reorganization is initiated in RA614.

Many of the cells of both strains with condensed nuclei, or no nucleus, possessed abnormally thick microtubules (2-3 times as thick as normal microtubules; Fig. $\left.7 c, c^{\prime} ; e, e^{\prime}\right)$. It was not possible to tell whether these thick structures were composed of bundles of microtubules of normal thickness or single, abnormally thick microtubules. Most of the anucleate cells did not have a MTOC (RA376: 11/19; RA614: 15/16; Fig. 7c, $c^{\prime}$ ) and the rest had only one. For both strains, the majority (55$66 \%$ ) of the cells with condensed nuclei possessed one or more MTOCs (Fig. 7e, $e^{\prime}$ ); this is a lower frequency than observed for cells with one or two normal nuclei. This difference may, however, be a consequence, rather than a cause of cell degeneration. A few cells with more than two condensed nuclei were observed (Fig. $7 b, b^{\prime} ; d, d^{\prime}$ ) in npfLl cultures.

\section{Discussion}

Genetic analysis indicated that the $n p f L 1$ mutation carried by RA614 was a single gene mutation unlinked to any of the marker genes tested. Abnormal development of strains carrying $n p f L 1$ ended in cell death; this is the first report of such a developmental mutant in Physarum polycephalum. Our study of the events leading to cell death in RA614 showed that the npfLI mutation did not affect amoebal proliferation, and that development in the mutant was identical to that in the $n p f L^{+}$parent until the mitosis at the end of the extended cell cycle. After the end of the long cell cycle in developing cells of RA614, a number of developmental events occurred. Events typical of plasmodium development included disappearance of the amoeba-specific $\alpha 3$-tubulin isotype; appear- 
ance of the plasmodium-specific $\beta 2$-tubulin isotype; the presence of extra MTOCs at mitosis in some developing uninucleate cells; the appearance of plasmodial (Class II) mitotic arrays; and acquisition of plasmodial fusion behaviour and the ability to ingest amoebae. Abnormal events included nuclear fusion at mitosis and in interphase; the appearance of abnormal mitotic spindles (Classes IV and V) and abnormally thick microtubules; the appearance of cells with condensed nuclei and the development of cells that rounded up and showed the 'boiling' phenotype. All developing cells in the $n p f L 1$ cultures eventually died. The stage of plasmodium formation at which normal development ceased was variable. In $n p f L^{+}$strains, there was similar variability in the timing of developmental changes in tubulin isotype expression, microtubular organization and cell behaviour, suggesting that variability was a normal part of plasmodium development (Blindt, 1987; Bailey et al., 1987, 1990; Solnica-Krezel et al., 1990, 1991). Our film of RA376 showed that there was also variability in the events at the end of the extended cell cycle; some developing cells divided rather than becoming binucleate and later became binucleate without passing through another long cell cycle. It was not surprising, therefore, that the time at which developmental abnormalities were first observed in RA614 was also variable.

Even after $n p f L l$ cells became visibly abnormal, some facets of normal plasmodium behaviour were observed, such as plasmodial fusions and ingestion of amoebae. These observations suggest that plasmodium development involved a number of pathways, some of which could continue even though other pathways were blocked in the absence of the $n p f L^{+}$gene product. This may make it difficult to deduce where the primary lesion lies. Many of the features of abnormal development in RA614 were also shown by a minority of RA376 cells. Events occurring exclusively in RA614 were nuclear fusion at mitosis and in interphase, and the formation of multipolar Class V spindles.

Since both amoebal and plasmodial nuclei possess a MTOC that organizes the spindle (Havercroft \& Gull, 1983), fusion of nuclei at mitosis or in interphase would result in polyploid nuclei with multiple MTOCs (one from each of the fusing nuclei), and some or all of the MTOCs could remain active. Akhavan-Niaki et al. (1991) demonstrated that the presence of multiple MTOCs in amoebae or plasmodia led to the formation of spindles with three or more poles. A few of the multipolar spindles (Class V) seen in RA614 were tripolar with the DNA equally distributed between the poles; this type of spindle is characteristic of diploid amoebae (Lemoine $e t$ al., 1984; Bailey et al., 1990) which ocur at a low frequency even in vegetative cultures of amoebae. Most multipolar spindles seen in RA614, however, occurred in developing cells and had more than three spindle poles with the DNA unequally divided between the poles (Fig. 6). This type of spindle has not been reported before and appears to be specific to development in $n p f L 1$. It seems likely that the multipolar spindles were a consequence of the nuclear fusions that were specific to developing $n p f L 1$ cells.

Nuclear fusion at mitosis in RA614 could have occurred by spindle fusion. In the ATS23 temperaturesensitive mutant (Burland et al., 1981), cytokinesis failed in amoebae grown at the restrictive temperature, resulting in multinucleate amoebae that later underwent nuclear fusion at mitosis, presumably as a result of spindle fusion. Spindle fusion would explain the observation that, during filming, two RA614 cells entered mitosis with four nuclei but reconstructed only two giant nuclei. However, such fusions could only occur in cells undergoing astral amoebal mitosis and not in cells undergoing intranuclear plasmodial mitosis and thus would not normally occur in multinucleate plasmodia. Our observations indicated that some mitotic multinucleate $n p f L 1$ cells formed amoebal spindles in which asters radiated from the spindle poles; it seems likely that spindle fusion would occur in these cells. Thus, a characteristic of some developing $n p f L 1$ cells may be an incomplete alteration to the plasmodial type of spindle.

Nuclear fusion at interphase normally occurs only in sexual interactions. When two amoebae carrying different mat $A$ alleles fused, nuclear fusion followed, in interphase, about two hours after amoebal fusion (Bailey et al., 1990). Since ability to undergo interphase nuclear fusion occurred only in mat $A$-heteroallelic fusion cells, fusion may have been switched on by the presence of two unlike $m a t A$ alleles in the same cell and was presumably switched off by the time of binucleate plasmodium formation. If, as a result of the gad mutation, a corresponding period of nuclear-fusion competence occurred in apogamic development, there would not usually be any consequence because the cells would be uninucleate at that time. If, however, the $n p f L 1$ mutation prolonged the period of nuclear-fusion-competence, the observed interphase nuclear fusions would occur. The $n p f L 1$ mutation may thus affect a developmentally associated alteration in nuclear structure.

Although nuclear fusion and multipolar spindles were observed only in RA614, a number of other abnormal features (nuclear condensation and the terminal 'boiling' phenotype) seen in developing RA614 cells were also observed at low frequency in RA376. Mutation in the $n p f L$ gene was thus not the only possible cause of these events. These features are also characteristic of cells dying by apoptosis (Kerr et al., 1972), a process of cell death observed during morphogenesis in many eukaryotes (Giorgi \& Deri, 1976; Robertson \& Thomson, 
1982) and in cells exposed to a number of cytotoxic agents and during tumour growth (Sorensen et al., 1990; Martin et al., 1990). There are typically three phases of apoptosis (Wyllie, 1988); firstly, chromatin condensation, nucleolar disintegration and a reduction in nuclear and cell size, with an increase in cytoplasmic density and extensive blebbing of the cytoplasm; secondly, cells may fragment into small membrane-bound apoptotic bodies which, in tissues, are phagocytosed and degraded by neighbouring cells; thirdly, the residual nuclear and cytoplasmic structures disintegrate as the cells swell and the membranes rupture.

Sanderson (1976) showed by time-lapse cinematography that mastocytoma cells in apoptosis exhibit cytoplasmic 'boiling' and an increased cytoplasmic density remarkably similar to that shown by $n p f L I$ cells. Some terminally differentiated RA614 cells burst after the onset of cytoplasmic 'boiling'. The condensed nuclei seen in our study appeared similar to nuclei isolated from apoptotic cells (Arends et al., 1990); both are about half the area of normal nuclei, lack nucleoli and stain intensely. In the later stages of apoptosis, nuclear fragmentation occurs (Wyllie, 1988). The anucleate cells we observed after DAPI staining could have resulted from nuclear fragmentation in cells with condensed nuclei.

Many cells with condensed nuclei were characterized by the presence of unusually thick microtubules. Although microtubules have not been studied in detail in apoptotic cells, it is interesting to note that some apoptotic cells contain bundles of cytoplasmic fibrils of unknown composition (Wyllie et al., 1984) and that apoptosis can be induced by treatment with microtubuledisrupting agents but not by disruption of microfilaments (Martin \& Cotter, 1990). The similarities between apoptosis and the changes observed during abnormal development in RA614 and RA376 suggest that cell death by an apoptosis-like mechanism may occur as a consequence of the breakdown of normal plasmodium development.

We thank Dr J. Lawry for running the flow cytometry samples on the Sheffield University FACS machine purchased by Yorkshire Cancer Research Campaign. We also thank Prof. W. Dove, Dr T. Burland and Dr D. Cunningham for comments on the manuscript, and S. Parkinson for technical assistance. We are very grateful to Dr E. Holler for suggesting apoptosis as a cause of the terminal phenotype of RA614.

J.B., R.W.A. and J.D. are grateful to SERC for financial support (Grant No. GR/D34530). L.S.-K. wishes to acknowledge support from Core Grant CA-07175 and Program-Project Grant in Tumor Biology CA-23076 from the National Cancer Institute. L.S.-K. was also supported by a Wisconsin Power and Light Foundation Fellowship in Cancer Research dedicated to the memory of employees and retirees of Wisconsin Power and Light Company who suffered or died as a result of cancer.

\section{References}

Adler, P. N. \& Holt, C. E. (1977). Mutations increasing asexual plasmodium formation in Physarum polycephalum. Genetics $\mathbf{8 7}, 401$ 420.

Akhavan-Niaki, H., Mir, L., Oustrin, M. L., Moisand, A. \& WRIGHT, M. (1991). Genetic analysis of the relationships between the amoebal extranuclear spindle-organizing centre and the plasmodial intranuclear spindle-organizing centre of Physarum during conjugation. Journal of Cell Science 99, 265-271.

ANDERSON, R. W. (1979). Complementation of amoebal-plasmodial transition mutants in Physarum polycephalum. Genetics 91, 409-419.

ANDERSON, R. W. \& DEE, J. (1977). Isolation and analysis of amoebalplasmodial transition mutants in the Myxomycete Physarum polycephalum. Genetic Research 29, 21-34.

Anderson, R. W., CoOKe, D. J. \& DeE, J. (1976). Apogamic development of plasmodia in the myxomycete Physarum polycephalum: A cinematographic analysis. Protoplasma 89, 29-40.

Anderson, R. W., DeE, J. \& Gull, K. (1986). Cellular transformations of myxamoebae. In The Molecular Biology of Physarum polycephalum, pp. 111-130. Edited by W. F. Dove, J. Dee, S. Hatano, F. B. Haugli \& K.-E. Wolfarth-Bottermann. New York: Plenum Press.

Anderson, R. W., Hutchins, G., Gray, A., Price, J. \& Anderson, S. E. (1989). Regulation of development by the mat $A$ complex locus in Physarum polycephalum. Journal of General Microbiology 135 1347-1359.

Arends, M. J., Morris, R. G. \& Wyllie, A. H. (1990). Apoptosis: The role of the endonuclease. American Journal of Pathology 136, 593-608.

Bailey, J., ANDERson, R. W. \& DEE, J. (1987). Growth and development in relation to the cell cycle in Physarum polycephalum. Protoplasma 141, 101-111.

Bailey, J., Anderson, R. W. \& DeE, J. (1990). Cellular events during sexual development from amoeba to plasmodium in the slime mould Physarum polycephalum. Journal of General Microbiology 136, 739751.

BLINDT, A. B. (1987). Changes in cellular organisation during apogamic development in Physarum polycephalum. $\mathrm{PhD}$ thesis, University of Leicester, Leicester, UK.

Blindt, A. B., Chainey, A. M., Dee, J. \& Gull, K. (1986). Events in the amoebal-plasmodial transition of Physarum polycephalum studied by enrichment for committed cells. Protoplasma 132, 149-159.

BURLAND T. G. (1986). Genetic analysis in Physarum polycephalum. In The Molecular Biology of Physarum polycephalum, pp. 19-38. Edited by W. F. Dove, J. Dee, S. Hatano, F. B. Haugli and K.-E. WolfarthBottermann. New York: Plenum Press.

Burland T. G., Chainey, A. M., Dee, J. \& Foxon, J. L. (1981). Analysis of development and growth in a mutant of Physarum polycephalum with defective cytokinesis. Developmental Biology 85, 26-38.

Crissman, H. A. \& Tobey, R. A. (1974). Cell-cycle analysis in 20 minutes. Science 184, 1297-1298.

DEE, J. (1986). The culture of Physarum amoebae in axenic media. In The Molecular Biology of Physarum polycephalum, pp. 255-270. Edited by W. F. Dove, J. Dee, S. Hatano, F. B. Haugli and K.-E. Wolfarth-Bottermann. New York: Plenum Press.

DEE, J. \& ANDERSON, R. W. (1984). The effect of ploidy on the stability of plasmodial heterokaryons in Physarum polycephalum. Journal of General Microbiology 131, 1167-1179.

DeE, J., Foxon, J. L. \& ANDERSON, R. W. (1989). Growth, development and genetic characteristics of Physarum polycephalum amoebae able to grow in liquid axenic media. Journal of General Microbiology 135, 1567-1588.

Diggins-Gilicinski, M., Solnica-Krezel, L., Burland, T. G., Paul, E. C. A. \& Dove, W. F. (1989). The localization of the divergent $\beta 2$ tubulin isotype in the microtubular arrays of Physarum polycephalum. Journal of Cell Science 94, 217-226.

GIORGI, F. \& DERI, P. (1976). Cell death in ovarian chambers of Drosophila melanogaster. Journal of Embryology and Experimental Morphology 35, 521-533.

Gull, K., Birkett, C. R., Blindt, A. B., Dee, J., Foster, K. E. \& Paul, E. C. A. (1985). Expression of a multi-tubulin family and th' in vivo assembly of microtubular organelles in Physarum polycephalum. 
In Microtubules and Microtubule Inhibitors, pp. 101-110. Edited by M. de Brabander and J. de Mey. Amsterdam: Elsevier Science Publishers.

HAVERCROFT, J. C. \& Gull, K. (1983). Demonstration of different patterns of microtubule organisation in Physarum polycephalum myxamoebae and plasmodia using immunofluorescence microscopy. European Journal of Cell Biology 32, 67-74.

KaWANo, S., KuroIWa, T. \& ANDERson, R. W. (1987). A third multiallelic mating-type locus in Physarum polycephalum. Journal of General Microbiology 133, 2539-2546.

KerR, J. F. R., Wyllie, A. H. \& CURRIE, A. R. (1972). Apoptosis: A basic biological phenomenon with wide-ranging implications in tissue kinetics. British Journal of Cancer 26, 239-257.

LemoINe, A., MIR, L. \& WRIGHT, M. (1984). Indirect immunofluorescent staining of the microtubules in interphase and mitotic amoebae of Physarum polycephalum. Protoplasma 120, 43-50.

Martin, S. J. \& CotTer, T. G. (1990). Disruption of microtubules induces an endogenous suicide pathway in human leukemia HL-60 cells. Cell and Tissue Kinetics 23, 545-559.

Martin, S. J., LenNon, S. V., Bonham, A. M. \& CotTer, T. G. (1990). Induction of apoptosis (programmed cell death). in human leukemic HL-60 cells by inhibition of RNA or protein synthesis. Journal of Immunology 145, 1859-1867.

Robertson, A. M. G. \& Thomson, J. N. (1982). Morphology of programmed cell death in the ventral nerve cord of Caenorhabditis elegans larvae. Journal of Embryology and Experimental Morphology 67, 89-100.

Salles-Passador, I., Moisand, A., Planques, V. \& Wright, M. (1991). Physarum plasmodia do contain cytoplasmic microtubules! Journal of Cell Science 100, 509-520.

SANDERSON, C. J. (1976). The mechanism of T cell mediated cytotoxicity. II. Morphological studies of cell death by time-lapse microcinematography. Proceedings of the Royal Society of London, Series $B$ 192, 241-255.

ShINNICK, T. M. \& HolT, C. E. (1977). A mutation (gad) linked to $m t$ and affecting asexual plasmodium formation in Physarum polycephalum. Journal of Bacteriology 131, 247-250.

Solnica-Krezel, L., Diggins-Gilicinski, M., Burland, T. G. \& DoVE, W. F. (1990). Variable pathways for developmental changes in composition and organisation of microtubules in Physarum polycephalum. Journal of Cell Science 96, 383-393.

SolniCA-Krezel, L., Burland, T. G. \& Dove, W. F. (1991). Variable pathways for developmental changes of mitosis and cytokinesis in Physarum polycephalum. Journal of Cell Biology 113, 591-604.

Sorensen, C. M., Barry, M. A. \& Eastman, A. (1990). Analysis of events associated with cell cycle arrest at $G 2$ phase and cell death induced by cisplatin. Journal of the National Cancer Institute 82, 749755.

Sweeney, G. E., WatTs, D. I. \& TuRnock, G. (1987). Differential gene expression during the amoebal-plasmodial transition in Physarum. Nucleic Acids Research 15, 933-945.

TAYLOR, I. W. \& MilthoRPE, B. K. (1980). An evaluation of DNA fluorochromes, staining techniques and analysis for flow cytometry. Journal of Histochemistry 28, 1224-1232.

WYLLIE, A. H. (1988). Apoptosis. ISI Atlas of Science: Immunology 1, 192-196.

Wyllie, A. H., MorRis, R. G., SMITH, A. L. \& Dunlop, D. (1984). Chromatin cleavage in apoptosis: association with condensed chromatin morphology and dependence on macromolecular synthesis. Journal of Pathology 142, 67-77.

Youngman, P. J., Adler, P. N., Shinnick, T. M. \& Holt, C. E. (1977). An extracellular inducer of asexual plasmodium formation in Physarum polycephalum. Proceedings of the National Academy of Sciences of the United States of America 74, 1120-1124. 